\title{
Article \\ Voluntary Sustainability Standards: State of the Art and Future Research
}

\author{
Axel Marx *, Charline Depoorter and Ruth Vanhaecht
}

check for updates

Citation: Marx, A.; Depoorter, C.; Vanhaecht, R. Voluntary

Sustainability Standards: State of the Art and Future Research. Standards 2022, 2, 14-31. https://doi.org/ $10.3390 /$ standards 2010002

Academic Editor:

Mário José Baptista Franco

Received: 20 October 2021

Accepted: 12 November 2021

Published: 4 January 2022

Publisher's Note: MDPI stays neutral with regard to jurisdictional claims in published maps and institutional affiliations.

Copyright: (C) 2022 by the authors. Licensee MDPI, Basel, Switzerland. This article is an open access article distributed under the terms and conditions of the Creative Commons Attribution (CC BY) license (https:// creativecommons.org/licenses/by/ $4.0 /)$.
Leuven Centre for Global Governance Studies, University of Leuven, 3000 Leuven, Belgium; charline.depoorter@kuleuven.be (C.D.); ruth.vanhaecht@student.kuleuven.be (R.V.)

* Correspondence: axel.marx@kuleuven.be

\begin{abstract}
In this feature paper, we introduce voluntary sustainability standards (VSS) and canvas the research that has been conducted on VSS from different academic disciplines. We identify four main areas of research on VSS and explore them. First, we focus on research on the institutional design of VSS, which highlights the diversity among VSS. Next, we explore studies that try to assess the impact of VSS on key sustainability dimensions. Third, we zoom in on studies that analyse the uptake or adoption of VSS. Finally, we focus on the interaction between VSS and public policies. For each of the four areas, we summarise the main research findings and identify opportunities for future research.
\end{abstract}

Keywords: voluntary sustainability standards; effectiveness; impact; adoption; design; institutionalisation

\section{Introduction}

Standards come in many forms and shapes. In this contribution, we focus on what has been more recently referred to as Voluntary Sustainability Standards (VSS), also called sustainability certificates, eco-labels or private standards. In this paper, we aim to provide the state of the art on VSS research by focusing on selected key research areas. For each research area, we summarise the main research findings and identify main avenues for future research.

There is no fixed definition of VSS, but the United Nations Forum on Sustainability Standards (UNFSS) defines them as "standards specifying requirements that producers, traders, manufacturers, retailers or service providers may be asked to meet, relating to a wide range of sustainability metrics, including respect for basic human rights, worker health and safety, the environmental impacts of production, community relations, land use planning and others" [1] (p. 4). VSS are considered as a significant private, market-based transnational governance instrument to pursue sustainable development. VSS initiatives have procedures to develop and set standards on a wide range of sustainability issues, and have systems in place to assess and monitor conformity with standards. Often, VSS use independent third parties to perform conformity assessments. They also issue certificates to their adopters in case of compliance and allow them to label their products accordingly. Well-known examples of VSS include Fairtrade International, Rainforest Alliance and the Forest Stewardship Council. Over the past few decades, VSS have proliferated [2]. Depending on the source used, the number of existing VSS globally ranges between 300 and 500.

VSS have received significant scholarly attention and many studies have been published on the topic in various academic disciplines, from sociology, political science, international relations and law to development studies, (agricultural) economics, geography, anthropology, forestry and ecology/earth sciences. In this paper, we aim to take stock of some of this research and identify possible avenues for future research. We organise the paper around four main areas of research that can be identified in the academic literature on VSS: the design of VSS and how they operate, the effectiveness of VSS in terms of 
impact on key sustainability dimensions, the effectiveness of VSS in terms of adoption and uptake, and finally, the institutionalisation of VSS in public policy. For each area, we identify the main research lines and findings and propose avenues for future research in order to better understand the potential and limitations of VSS as governance instruments for sustainability.

\section{Institutional Design of VSS}

Several studies have been published on understanding the diversity of VSS as institutions. Many explore the variation in the institutional design of VSS, with a specific focus on their standard-setting process as well as the enforcement of standards. Four streams of research highlight different aspects of VSS institutional design.

A first and early stream of research focused on the legitimacy of VSS as transnational governance instruments. To conceptualise and analyse legitimacy in relation to VSS, many researchers build on the work by Scharpf [3], who introduced the notions of input and output legitimacy. Input legitimacy focuses on the rule-making or standard-setting process and can be assessed by examining whether standards are developed according to a set of procedural requirements, such as representation of relevant stakeholders, inclusiveness, transparency and deliberativeness [4]. This line of research has particularly focused on which actors are involved in the standard-setting process. Some authors argue that VSS are remarkably democratic and inclusive in standard-setting [5], while others are more sceptical and critical, and highlight that key actors such as producers are hardly represented in the standard-setting process [6]. Output legitimacy relates to the degree to which decision makers can be held to account after decisions are made. Output legitimacy echoes the notion of "accountability as responsiveness" [7-9], which, as Gulbrandsen describes, focuses on the "relationship between the standard organisation and various stakeholders" [8] (pp. 566-567). This notion helps capture the degree to which "power wielders" meet "the expectation of relevant constituencies", accept "answerability on the disposal of their power", and act upon "criticisms or demand made of them" [8] (p. 567). To analyse output legitimacy, researchers have focused on complaint systems of VSS as accountability mechanisms [10]. Some researchers criticised these approaches to legitimacy as they tend to leave out questions related to the broader societal acceptance of an organisation's policies, structures and operations [11]. This has been addressed by scholars using a more sociological approach to legitimacy and has led to assessing the attitudes and perceptions of the communities in which the institution in question operates. With respect to VSS, this form of legitimacy is considered particularly important since private transnational governance systems do not possess any form of de jure (legal) legitimacy and must in effect more actively seek social support and recognition from a wide variety of members, stakeholders and observers [11-13]. These approaches have been applied to several VSS [7,14].

A second stream of research focuses on the substance of standards and analyses on what social, economic and environmental aspects standards are set and how stringent these standards are [15]. This line of research also includes a focus on which international norms, conventions and agreements these standards are based on. Concerning the latter, some authors argue that VSS are firmly rooted in existing international law and, in this way, do not create new rules or commitments but operationalise existing international commitments [16]. This stream of research also focuses on the debate which results in standards' dilution or weakening on the one hand, and standards' strengthening on the other hand, with a specific focus on corporate co-option leading to greenwashing [17-19].

A third stream of research focuses on how standards are enforced. Here, a significant body of literature discusses the use of independent third-party auditing, highlighting the many deficiencies in the audit approach [20-22]. Other scholars have complemented this line of research by focusing on another enforcement tool, namely the use of complaint and grievance mechanisms by VSS to continuously monitor compliance with standards [10,21]. Concerning audits, studies focused on different aspects. First, the quality of information on compliance with standards in auditing has been questioned since auditing leads to 
standardisation and routinisation resulting in auditors executing a "quick job" and missing crucial information [22,23]. Some observers [20] also argue that there is an inherent conflict of interests (as auditors are paid by standards adopters) which results in auditors having incentives to underreport practices and give in on the stringency of their audit reports in order to maintain clients. In addition, audits are only performed sporadically. Due to the dynamics in value chains, it is impossible to comply with all requirements and standards [20]. The deficiencies of the audit system led to the development of additional forms of monitoring and conformity assessment with a specific focus on complaint and grievance mechanisms. In order to provide continuous monitoring, one needs multiple "eyes" or auditors who are constantly available to monitor on-the-ground conditions. Hence, some authors have argued that dispute or complaint systems provide for "secondorder monitoring" [24] and could strengthen the enforcement potential of VSS [10,25].

A fourth stream of research seeks to bring these elements together and looks at how different components of institutional design combine in the context of specific VSS or provide a comparative analysis of several VSS on their institutional design [26-28]. This line of research highlights that there is significant variation on how VSS are designed in relation to how standards are set, how ex ante conformity is assessed through audits, whether or not they use complaint systems and how transparent they are. This diversity shows that not all VSS are equal in terms of design and, ultimately, effectiveness. In this stream of research, researchers have also tried to understand what influences the design of VSS. Recently, Van der Ven [29] argued that the use of VSS by large consumeroriented retailers influences the design and credibility of VSS since VSS targeting these firms specifically want to insulate them from critical scrutiny. Hence, they develop stringent systems to provide more reassurance to firms that they are complying with sustainability commitments through their value chains.

For future research on the institutional design of VSS, we propose two main avenues. First of all, little research has focused on how VSS change over time and develop new forms of standard-setting and standard implementation. The initial governance model of VSS largely relied on a structure in which VSS kept arms-length relationships with certificate holders in order to preserve independence and foster compliance with standards. Conformity with standards was often assessed by independent third parties in order to ensure compliance. Over time, the compliance logic has been challenged with a logic of learning which might generate better sustainability impacts [30]. Little research has focused on how VSS aim to generate learning and how this has affected the ways in which they operate. Secondly, little is known about how different ways of governing standards influence sustainability outcomes. Research on governance and research on impact have largely been conducted independently. Understanding how the governance of VSS influences their impact deserves more scholarly attention.

\section{Effectiveness of VSS: Impact on Sustainability Dimensions}

A second major area of research constitutes studies that aim to assess the impact of VSS on the ground. This area of research aims to answer the following questions: does the implementation of VSS have the desired influence on the issues that they aim to tackle? Are VSS fit for purpose, or, put simply, do they work? Several hundreds of studies have been published on the impact of VSS. Here, we present the focus and findings of literature reviews which assess several impact studies, as well as the data available on online platforms on VSS impacts. Concerning the former, we present the reviews of the International Trade Centre (ITC), the Food and Agricultural Organisation (FAO), the Meridian Institute (MI) and Oya et al. For the latter, the data gathered by two online platforms, Evidensia and Mongabay's Conservation Effectiveness, are summarised and discussed [31,32].

Table 1 lists nine literature reviews on the impact of VSS and provides an overview of some key characteristics of the studies included in the reviews, including which VSS are most studied, on which commodities they focus on, the countries/regions most studied 
and the number of studies in the review. Each of these literature reviews summarises studies that use different methodological approaches, from qualitative approaches to semiexperimental quantitative approaches.

Table 1. Overview of the characteristics of the studies under review.

\begin{tabular}{|c|c|c|c|c|}
\hline Review & VSS & Countries & Commodities & No. Studies \\
\hline ITC-GVCs [33] & Fairtrade & $\begin{array}{c}\text { Kenya } \\
\text { South Africa } \\
\text { Zambia }\end{array}$ & $\begin{array}{c}\text { Coffee } \\
\text { Flowers } \\
\text { Fruits and vegetables } \\
\text { Forestry products }\end{array}$ & 54 \\
\hline ITC-Producers [34] & $\begin{array}{l}\text { Fairtrade } \\
\text { Organic }\end{array}$ & $\begin{array}{l}\text { Costa Rica } \\
\text { Uganda } \\
\text { Kenya }\end{array}$ & $\begin{array}{l}\text { Coffee } \\
\text { Forestry }\end{array}$ & 56 \\
\hline ITC-Interplay [35] & Not specified & Not specified & Not specified & 78 \\
\hline ITC-Context [36] & $\begin{array}{l}\text { General } \\
\text { Fairtrade } \\
\text { FSC }\end{array}$ & $\begin{array}{c}\text { Multi-regional/global } \\
\text { Latin America } \\
\text { Africa }\end{array}$ & $\begin{array}{c}\text { General } \\
\text { Coffee } \\
\text { Forestry products } \\
\text { Fruits and vegetables }\end{array}$ & 59 \\
\hline FAO [37] & $\begin{array}{l}\text { GLOBALG.A.P. } \\
\text { Fairtrade } \\
\text { Organic }\end{array}$ & $\begin{array}{c}\text { Kenya } \\
\text { Mexico } \\
\text { Peru } \\
\text { Costa Rica } \\
\text { Uganda }\end{array}$ & $\begin{array}{c}\text { Coffee } \\
\text { Horticulture }\end{array}$ & 123 \\
\hline MI-Agri [38] & $\begin{array}{c}\text { RA } \\
\text { RSPO }\end{array}$ & $\begin{array}{l}\text { Colombia } \\
\text { Indonesia } \\
\text { Ethiopia }\end{array}$ & $\begin{array}{l}\text { Coffee } \\
\text { Palm oil }\end{array}$ & 16 \\
\hline MI-Forest [38] & FSC & $\begin{array}{l}\text { Southeast Asia } \\
\text { Latin America } \\
\text { Africa }\end{array}$ & Forestry products & 10 \\
\hline MI-Fish [38] & $\begin{array}{l}\text { MSC } \\
\text { ASC }\end{array}$ & $\begin{array}{c}\text { Vietnam } \\
\text { Australia } \\
\text { Mexico } \\
\text { Canada }\end{array}$ & $\begin{array}{c}\text { Marine fisheries } \\
\text { Aquaculture fisheries }\end{array}$ & 6 \\
\hline Oya et al. [39] & Fairtrade & $\begin{array}{c}\text { Latin America } \\
\text { Africa }\end{array}$ & Coffee & 43 \\
\hline
\end{tabular}

Overall, Table 1 shows that studies mostly focus on agricultural commodities and forestry in Sub-Saharan Africa and South America and tend to concentrate only on a limited number of VSS. All these studies focus on different sustainability impacts. The results point in different directions.

The Meridian Institute [38] reviewed the literature concerning conservation and environmental impacts of agricultural, forestry and fisheries VSS. Studies in Ethiopia and Colombia showed reduced deforestation rates on farms and plantations certified by Rainforest Alliance (RA) and RSPO. However, the studies conducted in Brazil and Indonesia did not report a significant effect. Furthermore, enhanced plant biodiversity was recorded on certified farms in Ethiopia and several Latin American countries. Overall, 50\% of the impacts are positive, while the other half show no significant effect of agricultural certification on conservation issues. With regard to fisheries certification, a limited number of studies on the MSC found an improvement in the status of the harvested population over time due to certification.

Concerning socio-economic impacts, Oya et al. [39] find positive impacts on prices, incomes from certified production and schooling, but also that the different VSS under study are not equally effective. Their analysis does not bring any clarity on the overall effect of certification on socio-economic issues across different certification schemes and 
commodities, making it impossible to draw general conclusions. Similarly, mixed results are reported in the studies of the ITC [33,34] and FAO [37]. The latter highlights that the adoption of VSS can improve smallholders access to Global Value Chains (GVCs) and to markets. This, however, does not guarantee immediate benefits. Long-term spillover effects in terms of competitiveness, such as the possibility to sell more non-certified products through market integration, can enhance profitability.

To assess the impacts of VSS more systematically, recent databases have been made available, of which Evidensia is the most prominent one. Evidensia is an online platform founded in 2019 by ISEAL Alliance, Rainforest Alliance and the World Wildlife Fund, and gathers all the relevant and reliable primary and secondary literature about the impact of market-based sustainability tools and supply chain initiatives on multiple sustainability issues [40]. The platform provides the option of accessing the results of impact studies visually with the "Visual Summaries". This tool makes it possible to gain insight into the number of specific outcomes, reported concerning a multitude of sustainability issues [41]. The Visual Summaries provide information on the environmental and economic impact of certification by several VSS applied to the agricultural and forestry sectors. To evaluate VSS environmental impact, issues such as carbon sequestration, soil erosion or species richness are evaluated. For example, if a study shows that the species richness in a certified region is significantly higher than in an uncertified region, a positive impact on species richness due to certification is shown in the Visual Summaries. Evaluating the economic impact is performed by focusing on the household income, price premiums, product income and yield. For example, when a study shows a significant increase in the household income of a household that works in certified agriculture compared to conventional agriculture, a positive impact is shown in the Visual Summaries. The regions in which the impacts are measured are primarily Latin America; East, Central and West Africa; and East, South and Southeast Asia. Only two of the included studies executed their research in Europe, and none in North America. To provide comparable and credible results, the studies are selected against strict quality criteria concerning research design (statistical-based analysis which allows for isolating the effects of VSS and which compares a treatment group (VSS-certified) with a control group (not certified)) and need to be recent (not older than 10 years) [41]. The database contains information on almost 450 impacts. For each of them, the database reports whether it is a positive impact (the VSS group performs better than the control group), a neutral impact (there is statistically no difference between the VSS group and the control group) or a negative impact (the control group performs better than the VSS group).

Of the 447 impacts listed in the Visual Summaries, 205 are positive and 211 are neutral. Only 31 of the impacts appear to be negative. This trend continues when looking at the distinct impact categories. Table 2 reports 94 positive and 93 neutral impacts on environmental issues, and only nine negative impacts. For the socio-economic impact of the studied VSS, 111 positive impacts and 118 neutral impacts are found, in contrast with 22 negative impacts which are mainly related to increased costs linked to obtaining certification.

Table 2. Number of positive, neutral and negative impacts of VSS per issue category.

\begin{tabular}{cccc}
\hline Issue Category & Positive & Neutral & Negative \\
\hline Environment & 94 & 93 & 9 \\
Socio-Economic & 111 & 118 & 22 \\
Total & 205 & 211 & 31 \\
\hline
\end{tabular}

In Table 3 and Figure 1, the impacts extracted from studies that focus on a single country are shown. By filtering these, 379 out of a total 447 impacts remain. The countries in which most impacts were recorded are Nicaragua, Colombia, Ethiopia and Uganda. It is noteworthy that few studies have been conducted in Europe and the United States. 
Table 3. Number of positive, neutral and negative impacts of VSS per country.

\begin{tabular}{|c|c|c|c|}
\hline Country & Positive & Neutral & Negative \\
\hline Brazil & 4 & 5 & 1 \\
\hline Cameroon & 0 & 1 & 0 \\
\hline Chile & 3 & 1 & 0 \\
\hline China & 2 & 3 & 1 \\
\hline Colombia & 28 & 20 & 1 \\
\hline Côte d'Ivoire & 8 & 6 & 0 \\
\hline El Salvador & 3 & 2 & 0 \\
\hline Ethiopia & 16 & 15 & 3 \\
\hline Gabon & 5 & 4 & 0 \\
\hline Ghana & 2 & 7 & 0 \\
\hline Guatemala & 1 & 0 & 0 \\
\hline India & 13 & 13 & 2 \\
\hline Indonesia & 7 & 12 & 1 \\
\hline Kenya & 11 & 9 & 2 \\
\hline Madagascar & 2 & 0 & 0 \\
\hline Malaysia & 0 & 2 & 2 \\
\hline Mexico & 7 & 8 & 0 \\
\hline Nicaragua & 21 & 27 & 5 \\
\hline Pakistan & 7 & 3 & 1 \\
\hline Peru & 5 & 13 & 2 \\
\hline Portugal & 1 & 1 & 0 \\
\hline Rwanda & 0 & 2 & 1 \\
\hline Sweden & 0 & 5 & 0 \\
\hline Thailand & 2 & 2 & 0 \\
\hline Uganda & 17 & 10 & 6 \\
\hline $\begin{array}{c}\text { United Republic of } \\
\text { Tanzania }\end{array}$ & 4 & 2 & 0 \\
\hline Vietnam & 4 & 5 & 0 \\
\hline Total & 173 & 178 & 28 \\
\hline
\end{tabular}

\section{Positive Impacts per Country}

Number of positive impacts

\section{Neutral Impacts per Country}

Number of neutral impacts

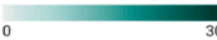

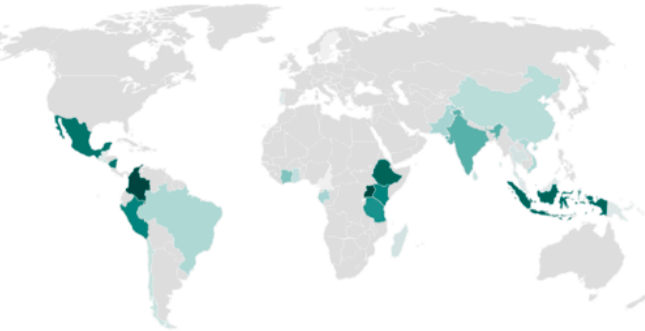

Negative Impacts per Country

Number of negative impacts

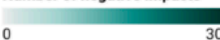

Maps created by the authors with mapchart.net

Figure 1. Global distribution of the positive, neutral and negative impacts of VSS. 
The impacts that are extracted from studies that focus on a single VSS are isolated and listed in Table 4 , and 228 out of the total of 447 impacts of the platform remain. The three most studied VSS, i.e., with most impacts listed, are RA, UTZ and the FSC. RA seems to have an overall positive impact, with 41 positive impacts, compared to 23 neutral ones and one negative one. For the FSC, the number of positive and neutral impacts is comparable, with 15 positive impacts and 13 neutral ones, and no negative impact. For UTZ, the neutral impacts recorded are almost double the positive ones, with 11 positive impacts and 21 neutral ones.

Table 4. Number of positive, neutral and negative impacts per VSS.

\begin{tabular}{cccc}
\hline VSS & Positive & Neutral & Negative \\
\hline 4C Association & 2 & 6 & 0 \\
Better Cotton Initiative (BCI) & 7 & 3 & 1 \\
Bird Friendly & 6 & 6 & 0 \\
Eurep GAP & 1 & 1 & 0 \\
Fairtrade International & 5 & 7 & 1 \\
Forest Stewardship Council (FSC) & 15 & 13 & 0 \\
GLOBALG.A.P. & 6 & 5 & 0 \\
Green Food Program (China) & 0 & 2 & 2 \\
International Federation of Organic & 9 & 11 & 1 \\
Agriculture Movements (IFOAM) & 41 & 23 & 2 \\
Rainforest Alliance (RA) & 3 & 5 & 1 \\
Roundtable on Sustainable Palm Oil (RSPO) & 0 & 2 & 0 \\
Starbucks C.A.F.E. practices & 3 & 3 & 3 \\
Sustainable Agriculture Network (SAN) & 11 & 21 & 11 \\
UTZ & 109 & 108 & \\
Total & & &
\end{tabular}

The impacts extracted from studies that focus on a single commodity are listed in Table 5, and 436 out of 447 impacts remain. About $64 \%$ of the impacts come from studies focusing only on coffee production. The number of positive and neutral impacts are equal (both 130). About $8 \%$ of the impacts of VSS in coffee production is negative.

Table 5. Number of positive, neutral and negative impacts of VSS per commodity.

\begin{tabular}{cccc}
\hline Commodity & Positive & Neutral & Negative \\
\hline Banana (fresh) & 2 & 2 & 0 \\
Black pepper & 5 & 3 & 2 \\
Cocoa & 12 & 19 & 1 \\
Coffee & 130 & 130 & 21 \\
Cotton (raw) & 7 & 3 & 1 \\
Forestry plantations & 20 & 26 & 0 \\
Honey & 3 & 0 & 0 \\
Lychee & 2 & 0 & 0 \\
Palm oil & 3 & 5 & 2 \\
Peas & 1 & 0 & 0 \\
Rice & 11 & 16 & 1 \\
Strawberries & 1 & 2 & 0 \\
Tea & 4 & 1 & 0 \\
Total & 201 & 207 & 28 \\
\hline
\end{tabular}

The results from the Evidensia database on the FSC specifically correspond to the results from the Conservation Effectiveness database. Conservation Effectiveness is a community-sourced platform, founded in 2016. It is a collaboration between Mongabay, a conservation and environmental science news platform, and tropical forest ecologist and conservation scientists from the University of Wisconsin [31]. Conservation Effectiveness presents the environmental, social and economic impact of certification by the FSC. The evidence typology in Conservation Effectiveness is similar to Evidensia and focuses on statistical models which can isolate impact from other confounding variables [42,43]. 
Conservation Effectiveness reports on 72 impacts related to the FSC. The majority of the impacts of FSC is either positive or neutral (40 positive impacts and 27 neutral impacts); only five impacts are negative. Table 6 shows that the FSC appears to have the most positive impact on economic issues such as profits, pre-logging costs or price premiums. There is approximately the same amount of positive and neutral impacts on environmental and social issues.

Table 6. Number of positive, neutral and negative impacts of the FSC per issue category.

\begin{tabular}{cccc}
\hline Issue Category & Positive & Neutral & Negative \\
\hline Economic & 19 & 7 & 4 \\
Environmental & 12 & 13 & 1 \\
Social & 9 & 7 & 0 \\
Total & 40 & 27 & 5 \\
\hline
\end{tabular}

What do we learn from these studies in general? When are VSS effective in achieving sustainability improvements? It is difficult to draw any general conclusions since all studies point to the fact that impacts are case-specific and vary widely. Overall, there are more positive impacts than neutral or negative ones linked to certification, but this does not hold across VSS, commodities and countries. Based on the interpretation of the results, some general observations can be made.

It seems evident that the characteristics of the VSS influence their effectiveness. The ITC found that important characteristics to achieve the objectives are the sector of focus, the legitimacy of the VSS, the balance between more general applicability and suitability for local circumstances, and the existence of clear and short-term benefits incentivising adoption, such as immediate price premiums. Oya et al. [39] suggest that the mechanism used to influence the price paid to the producer (e.g., price premiums, price floors, etc.), and whether this approach is compatible with the target sector or target commodity, is determining for VSS impact. Secondly, the conditions of eligible actors (i.e., farmers, producers) seem to be an important factor. The FAO found that the ability of the exporters and farmers to achieve compliance is highly dependent on the capacity at the farm level since entering the GVCs requires a certain level of persistence [37]. Finally, the context is a crucial factor for the impact of VSS. Consisting of factors out of the realm of control of the certification system, implementation of the same VSS can have different outcomes in different contexts [39]. Two components seem to be important concerning this context. On the one hand, the characteristics of buyers and value chains are influential factors [36]. VSS are tools to enter global value chains and the degree to which they facilitate this will also determine their impact. Based on a limited number of studies, the adoption of VSS seems to be able to facilitate access to global value chains. The structure of the value chain plays an important role in the distribution of revenues [33]. Studies also underline how the barriers to enter the value chain becomes higher for smallholders, who face more difficulties to adopt standards. Some studies also find that revenues resulting from VSS adoption are unevenly distributed along the chain and sometimes in the benefit of major buyers in the value chain, such as retailers [33].

On the other hand, the broader political and policy environment in which VSS are implemented play a role. Several studies point to the relevance of this policy "embeddedness" for the efficient implementation of VSS. Therefore, the ITC advocates for more cooperation between standard setters, public authorities, international organisations and the private sector to achieve impacts [35]. Oya et al. come to similar conclusions [39]. More qualitative studies show that the agricultural and economic policy environment is decisive for the effectiveness of VSS [39]. Recognising the interplay between VSS and public institutions, the FAO argues that national governments can support and facilitate participation and standards implementation [37]. The ITC report agrees that support is needed, particularly in the case of smallholders entering global value chains. However, it remains unclear what kind of support would be most effective in which circumstances [33]. 
With regard to assessing VSS impacts, we propose four areas for future research. First, a limitation mentioned across all reviews is the overrepresentation of certain countries or regions, VSS and commodities in the existing literature. This research focus was mentioned in early studies [36]. Oya et al. [39], who conducted a review several years later, still mention how the majority of studies focus on the same regions, commodities and VSS. This also becomes apparent when screening the online databases. This lack of data and the high case-specificity in this field of research makes it impossible to draw global conclusions on the impacts across all VSS and sectors. Broadening this scope to other VSS and countries would constitute the first avenue for research.

Second, the research designs, methods of data collection and indicators used are research-specific and inhibit cross-research projects comparisons. The ITC suggests the use of standardised indicators in future research in order to enhance comparability.

Third, disentangling causality remains a conundrum. The ITC [35] reports that finding causal relations remains difficult since VSS trigger a diversity of interventions over a long period. As a result, VSS interventions are interrelated with other developments, making it difficult to identify the net effect of certification on sustainability. Moreover, the review from the FAO [37] highlights the importance of disentangling causal mechanisms since most current studies do not allow for a causal interpretation. To address this conundrum, research with mixed research designs should be conducted to combine quantitative analysis with qualitative analysis based on process-tracing, with a strong focus on how VSS interventions combine and interact with other types of interventions. To assess the causal link between a certain intervention and its outcome, VSS and their respective interventions should be disentangled [39].

A last area for future research should focus on linking VSS governance and design with their impacts. Overall, impact studies highlight that some VSS have more impact than others, and that some VSS are more effective in solving some sustainability issues rather than others. However, there remains a lack of understanding about why some VSS are more effective than others and what institutional design characteristics determine impact. Governance studies and impact studies have mostly been carried out independently and the links between governance and impacts remain largely hypothesised. More research is needed to understand how the design of VSS influences their impacts.

\section{Effectiveness of VSS: Adoption}

A third major area of research on VSS has explored the adoption of VSS, or their uptake. Adoption can be defined as the extent to which VSS are used and is an important component of VSS effectiveness as low adoption rates constrain the potential of VSS to create impacts on the ground. In order to significantly contribute to sustainability, VSS need to diffuse widely. Research on VSS adoption has generally revolved around two different questions: (1) Where and to what extent are VSS adopted? (2) Why are VSS adopted? Studies aiming to answer the first question have assessed where and to what extent VSS are adopted based on different units of analysis.

A first unit of analysis is situated at the country level. Studies have explored the distribution of VSS across countries and the uptake of specific VSS in specific countries. Research find that all countries have VSS active on their territory, but that there is significant variation in the number of VSS present across countries and in their coverage at country level $[2,44]$. These studies show that country-level VSS adoption is influenced by several economic and political factors. In an early study, van Kooten et al. [45] tried to identify the country-level conditions that encourage the growth of a private regulatory environmental system to govern forests. They examined 117 countries to identify factors determining forest certification under the Forest Stewardship Council and domestic competitor schemes. Besides economic factors (forestry products exports and GDP), they identified that political (size of government, structure of the economy and freedom to trade) and social (literacy rates and the degree of suppression of women) factors also play an important role in adoption. The importance of political factors for understanding VSS adoption is also 
highlighted in other studies. Bartley [46], for example, in a case study of Indonesia, argues that understanding the political context of a country is important for understanding the dynamics of forest certification adoption. Similarly, a literature review of more than 100 studies argued that a necessary, although insufficient, condition for VSS adoption is the presence of national institutions to provide a supporting environment for compliance with standards and regulatory compliance [37]. These studies point to the fact that countries which have developed effective and well-functioning governance structures constitute a better institutional context for VSS adoption.

Adoption studies across countries have also focused on the question of whether adoption is occurring in places most in need of sustainability improvements. Tayleur et al. [47] focused on VSS certifying tropical commodities-which are mainly produced in developing countries-and showed that VSS are located in countries or regions most important for biodiversity conservation, but not where poverty alleviation needs are direst. These findings show a selection bias in VSS systems that excludes the poorest countries [14]. To account for this bias, Marx and Cuypers have referred to the "stuck at the bottom problem", which argues that complying with VSS requirements is more difficult for countries most in need for sustainability improvements for two reasons [48]. First, there is a governance gap between government regulations, which are typically weaker in developing countries, and VSS requirements, which are more stringent. Producers and firms in developing countries are therefore used to operate under more lenient regulations, and complying with sustainability standards demands greater changes in practices. This can involve higher production costs and the need for technical capacity and know-how. In comparison, countries where government regulations are more stringent make it easier for producers to comply with VSS. Second, only producers that have prior income or assets have the potential to adopt VSS since certification involves significant costs, and smallholder farmers are typically discriminated in VSS markets.

A second unit of analysis of the extent of VSS adoption is the distribution of VSS across economic sectors. Much research has focused on the emergence and development of VSS in specific sectors with a main focus on garment and textile sector [49,50], forestry [17,49] and different agricultural commodities such as coffee, tea and cocoa [17]. This literature points to the different factors which induced the emergence of VSS in specific sectors and also accounts for the fact that one can observe many VSS in specific sectors. This line of research has also focused on the competition between standards in economic sectors and the relative lack of convergence and cooperation between VSS [51]. Based on an analysis of the ITC Standards Map and the Ecolabel Index, researchers also focused on the distribution of VSS across sectors [2]. Research points to great disparities in the number of VSS across sectors which result from differences in the structure and complexity of some global value chains and from the high price volatility for some commodities such as rubber, which make it difficult to set up VSS [52] (pp. 34-35).

Third, research has explored the extent of VSS uptake at commodity level by analysing both the share of production land certified globally and the share of production volume certified. These studies mainly focus on agricultural commodities and forests. According to different estimates, less than $2 \%$ of global cropland is currently certified, but research shows that this proportion is increasing over time, with an annual increase of about $11 \%[53,54]$. However, this low overall certification percentage hides variation between commodities. For example more than $25 \%$ of the global production volume of coffee and of cacao are certified, and more than $10 \%$ of global forests [55].

Common to these three strands of research on different units of analysis is the assumption that VSS adoption is growing rather steadily over time and across VSS. However, there are disparities in adoption across VSS, with some VSS being more adopted than others. Several interplaying factors can explain why some VSS diffuse more widely than others, including the net benefits they provide to adopters of standards [56-58], their recognition by governments $[59,60]$ and their stringency $[29,61,62]$-although a study by Castka and Corbett finds no link between stringency and adoption [57]. Besides, individual VSS can 
also experience fluctuations and even decline in their adoption. Research on the dynamics of VSS adoption and their determinants is lacking.

A second strand of research on VSS adoption has aimed to provide answers as to why VSS are adopted by exploring motives for adoption by (1) producers or firms along global value chains (e.g., producers, buyers, retailers), (2) consumers and (3) governments (see next section).

Firstly, studies have put forward five major motivations for producers and firms along global value chains to take up certification. First, producers and firms adopt VSS as a means to mitigate reputational risks [63-65]. With the increase in civil society campaigns and boycotts against firms whose activities bear adverse consequences on socioeconomic or environmental conditions, firms adopt VSS as proof of compliance with sustainability practices to protect their reputation. Second, VSS can yield a price premium for producers or firms as on some markets, certified products can be sold at higher prices $[48,65]$. However, research has also highlighted that price premiums are not guaranteed and depend on consumers' willingness to pay, on the presence of substitute goods and on oversupply of certified products $[62,66]$. In addition, even in the existence of a price premium, producers and suppliers do not always reap the benefits of certification as powerful actors in the value chain capture the premium [19] — what Ponte refers to as the "sustainability-driven supplier squeeze" [67]. Third, producers or firms use VSS as means to enter global value chains and increase their access to higher value markets. VSS can be considered as a tool to transfer information, or as a signalling mechanism to inform consumers, governments and other business actors about the sustainability of products or production methods $[58,66]$. VSS can increase market access via two channels: (a) as a differentiation mechanism, they can improve access to environmentally and socially sensitive markets [68]; and (b) they can provide market access when this latter is conditional on compliance with specific sustainability criteria by serving as proof of compliance with such requirements $[68,69]$. Fourth, VSS enable firms or producers to innovate. VSS constitute a knowledge transfer and learning mechanism by means of which those actors can implement more sustainable practices, sometimes allowing for efficiency gains $[30,68]$. Fifth and last, adoption of VSS by producers or firms along global value chains can be driven by individual ethical values and commitment to sustainability $[69,70]$. Yet, research shows that reputation management, price premium and market access remain the strongest drivers of VSS adoption [58]. In addition, the literature has highlighted an important shortcoming of VSS adoption along global value chains. VSS adoption by large buyers and retailers who have significant bargaining power and impose certification on their suppliers down the value chain can foster wider adoption of VSS [66,67]. However, this also contributes to the exclusion and marginalisation of suppliers-typically smallholder farmers in developing countries-who are not able to comply with VSS requirements [37,71,72].

Secondly, research have explored VSS adoption by consumers and have highlighted several challenges. VSS adoption by consumers refers to their purchase of certified products. This is driven by their sensitivity to sustainability issues related to production and consumption - what is called ethical consumerism - and whether such sensitivity translates into more sustainable purchasing practices, thus creating a consumer market for VSS. In the literature, the existence of a large consumer market for VSS remains debated. Increases in market shares of certified products in some sectors argue in favour of the existence of such market. For example, one can observe a strong increase in a number of certified products. In the Netherlands, $45 \%$ of the coffee sold on the Dutch market, in 2010, is certified, compared to only $2.9 \%$ in 2001 [73]. A similar increase, although not as outspoken, can be observed for other products. However, whether consumer demand is a strong driver for VSS adoption is currently hotly debated in the context of ethical consumerism. In a collection of papers by Dara O'Rourke [74] and the responses by several others, it emerges that there is indeed a consumer market for sustainable products, but how large this consumer market is remains unclear. Brenton [75], for example, raises doubts about the strength of consumer demand to support voluntary standards. He examines the political 
motivations underlying ethical consumption, such as its relationship to other forms of political activism and how existing values interact with consumption choices, and argues that many of the factors involved in consumer decision making are inconsistent with the assumptions made by private economic governance schemes in attempting to harness consumer power. Indeed, other studies show that individual consumers' demand for VSS depends on multiple factors including age, nationality, motivation, past experience with VSS, scepticism towards VSS, level of knowledge about VSS, need, accessibility, affordability, product performance or force of habit [76,77]. Another study highlights that there is demand for certified goods and that consumers (mainly in Europe and North America) will consciously choose for certified goods, but only if the price remains the same [78]. In addition, studies show that the proliferation of VSS on consumer markets has generated confusion among consumers about the missions of, differences between, and effectiveness of VSS $[79,80]$. This has undermined consumers' trust in VSS. Overall, findings highlight an "attitude-behaviour gap", meaning that the expression of consumers' willingness to buy certified products at higher prices does not necessarily materialise into more sustainable purchasing behaviours $[78,81]$. As a result, research shows that there is an oversupply of certified products in some markets as consumer demand has not kept up with supply, and hence, some certified products need to be sold as non-certified, as is the case in the coffee sector, for example [53].

Six main areas for future research on VSS adoption can be identified. First, significant research has investigated where VSS are active and which factors contribute to the uptake of VSS. Most researchers focus on explaining the uptake and growth of VSS and assume that the adoption dynamics of VSS are linear, i.e., that once a VSS is adopted in a country, it remains there and increases its coverage. However, in a recent paper focusing on the adoption of the FSC, Depoorter and Marx [82] show that VSS adoption dynamics are not linear and highlight several adoption dynamics, including saturation, stagnation and decline. Understanding these different dynamics constitutes a new area of research.

Second, there is a relatively sufficient understanding of some of the economic, political and social factors that are related to the adoption of VSS and the mechanism by which they induce VSS uptake. Yet, it is less clear how other factors, such as good governance and political context, influence VSS adoption. For example, we know countries that score well on good governance are hypothesised to have higher degrees of VSS adoption. However, the operationalisation of what exactly is understood under political institutional context and governance structure remains vague. As the FAO [37] notes, far more research is needed in this respect.

Third, concerning VSS adoption across economic sectors, most research has focused on the emergence of VSS in specific commodity sectors and the diffusion of the certification model over different sectors, but less research has focused on the non-emergence of VSS in other sectors. There are many economic sectors and commodities for which no VSS are available. Hence, understanding the barriers to VSS emergence requires more research.

Fourth, research is needed on how to foster VSS adoption in areas most in need for sustainability improvements. Research has shown that VSS are mostly active in countries with well-functioning governments and in regions that are important for biodiversity preservation, but not in areas most in need of poverty alleviation [47]. Hence, research is needed on how to scale up VSS adoption in a more strategic and targeted way. In this regard, case-based research could help understand how VSS can be improved and adjusted to specific contexts, and what complementarities they could present with other relevant actors to maximise sustainability improvements, e.g., through hybrid governance arrangements [83].

Fifth, research has highlighted that the adoption of VSS by powerful actors along global value chains can help diffuse them, hence contributing to their effectiveness. Future research should explore whether such diffusion channel is desirable and how to ensure that more vulnerable actors are included in certification dynamics and benefit from it. 
Lastly, further research needs to be conducted on how to foster and harness consumer demand for VSS and on the impact of recognition systems in that respect. Some organisations, such as the European Commission, are launching initiatives to reduce consumer confusion about VSS through recognition systems [84]-i.e., endorsing credible VSS based on minimum criteria. The potential of such recognition systems to foster consumer demand for VSS remains to be explored.

\section{Institutionalisation of VSS}

A fourth area of research which is emerging focuses on the so-called institutionalisation of VSS in public policy [83,85-87]. Institutionalisation of VSS in public policies occurs when references and functions of VSS are integrated in public policies. This integration of VSS can take different forms in different policy arrangements.

First, D'Hollander and Marx [88] have shown that VSS play a role in sustainable public procurement. The term "sustainable public procurement" is used to refer to socially and environmentally friendly public procurement policies. The latter implies that governments, from the local to the national level, buy goods and services which that with sustainability requirements. Given the purchasing power of governments, sustainable public procurement can have significant impact on a large variety of products. VSS play a specific and increasingly significant role since they are often integrated into the operationalisation of sustainable public procurement practices [88,89]. Second, VSS are increasingly referred to in the context of trade policy and efforts to make trade policy more sustainable. The UNFSS [2] analysed the degree to which one can find references to VSS in bilateral and multilateral free trade agreements. Marx [90] also explored ways in which VSS can be integrated in unilateral trade instruments such as the Generalised Scheme of Preferences. Third, some scholars have focused on the integration of VSS in specific regulations. In this context, researchers have focused on the integration of VSS in the EU Timber Regulation and analysed a new form of governance which is labelled by Jonathan Zeitlin and colleagues as "experimental governance" [91]. Attention has also gone to the EU Renewable Energy Directive, which established a set of sustainability criteria for biofuels, including environmental and social criteria. In order to ensure that biofuels are compliant with these criteria, recognised VSS provide proof of compliance with those criteria. The directive explicitly refers to VSS, and several scholars have analysed the potential and limitations of integrating VSS in public policy with the renewable energy directive as a case study [92,93].

Besides analysing how VSS are integrated in public policy based on specific case studies, some scholars have tried to understand what is driving this integration, while other scholars have tried to more systematically categorise this institutionalisation. Concerning the former, a study by Renckens [94] focuses on the integration of VSS in European Union policy making on organic agriculture, biofuels, fisheries and fair trade, and shows that in some cases, VSS are actively pursuing a strategy of being integrated in public policies which is accepted by policy makers, while in other cases, policy makers are more reluctant to integrate VSS in public policy. Drawing on European Union policy making on organic agriculture, biofuels, fisheries and fair trade, Renckens exposes the political and economic conflicts between private and public rule-makers and the strategic nature of regulating sustainability in a global economy. Based on these cases, he develops a new theory of public-VSS interactions focusing on the economic benefits to domestic producers and the degree of fragmentation of VSS schemes.

Concerning the categorisation, Lambin et al. [81] provide an overview of how private governance instruments such as VSS are integrated in public policy in the context of land-use management. They characterise public-private interactions as being either complementary, substitutive or antagonistic. "Complementary" involves states offering an enabling and supportive regulatory environment for VSS operations, or allowing them to fill in policy gaps; "substitutive" refers to governments absorbing existing VSS into public policies or laws by transforming private rules into public ones; and "antagonistic" refers to public and private rules prescribing conflicting practices. Marques and Eberlein [86] 
distinguish five types of public-private interactions of which two, "replace" and "reject", focus on government regulation replacing private regulation or outright rejecting private regulation. The other three types describe ways in which public regulation engages more positively with VSS. First, VSS can act as "substitutes" for public rules on matters which states are unable or unwilling to regulate, similar to Lambin et al.'s "complementary" role. Second, states can "adopt and support" VSS by acting as clients of certification for state-led production operations, providing administrative or financial support to domestic firms to comply with VSS, politically endorsing VSS or enacting policies that recognise VSS as proof of compliance with public requirements. Third, states can build on existing VSS and "repurpose" them to better fulfil public objectives.

We suggest two main topics for future research on the institutionalisation of VSS. First, the integration of VSS in public policies raises the question of how rule makers distinguish credible from non-credible standards. We know that many VSS are available for the governance of certain commodities. We also know that these VSS differ in institutional design, credibility and ultimately effectiveness. If one integrates VSS in public policies, one must ensure that one only integrates effective VSS. To distinguish credible from noncredible VSS, public policy makers must establish recognition systems. More research must be conducted on how these recognition systems are designed and what their impact is.

Second, little research is conducted on the impact of the integration of VSS in public policies on VSS themselves, both in terms of substantive standards which are covered, as well as with regard to the implementation and enforcement of standards. It could be hypothesised that VSS will change due to their integration in public policies. Little is known about what this change entails. The latter is especially relevant in the context of the emergence of new human rights due diligence regulations, which will impact producers all over the world [95]. These due diligence regulations, which are emerging in many countries, partially rely on VSS to ensure compliance with due diligence requirements.

\section{Conclusions}

Voluntary Sustainability Standards have emerged as a transnational governance tool in the 1990s. Although one can find earlier examples of VSS, the use and spread of VSS across commodity sectors to transnationally govern global value chains really took off in the 1990s and early 2000s. As a result, research on VSS started to emerge. More than 20 years after early studies on VSS, the research community focusing on VSS has grown and consolidated. Researchers from various disciplines including sociology, political science, international relations, law, development studies, (agricultural) economics, geography, anthropology, forestry and ecology/earth sciences have started to conduct research on VSS. This has led to an interdisciplinary research community exploring the different dimensions of research on VSS.

In this contribution, we aimed to map the major trends in research on VSS and identify some of the key findings. For each of the four trends (design, impact, adoption and institutionalisation), we propose different avenues for future research.

First, research has focused on understanding VSS as a new form of global governance in terms of how they are designed. Overall, this area of research has pointed to the high diversity in the institutional design of VSS. It calls for further research on how the design of VSS is evolving over time, and how it influences VSS impacts. Next, studies have analysed VSS effectiveness along multiple dimensions. Most prominently, research focused on the impact of VSS on a number of sustainability issues (environmental protection, labour rights, poverty alleviation, etc.) and on the adoption of VSS across countries, actors (consumers and business) and commodities. On the former (i.e., impact), research finds limited and context-specific evidence of the impacts of VSS, and highlights a lack of diversity in terms of countries, commodities and VSS studied, stemming from insufficient data availability and quality. This calls for more diversity in case study selection in terms of countries, commodities and VSS, as well as for the application of more diverse research designs, methods and data collection in order to address significant data gaps. On the latter (i.e., 
adoption), research finds unequal adoption of VSS across countries, sectors and commodities and identifies shortcomings in the motivation for business and consumers to adopt VSS. Further research is needed on the dynamics of VSS adoption, and on how to foster higher adoption in areas most in need for sustainability improvements as well as by consumers. Finally, research started to focus on the institutionalisation of VSS, in other words, how they are integrated in public policies with regard to trade, natural resources governance and public procurement among other policy areas. Exploring ways to distinguish credible VSS from non-credible ones and studying the impact of institutionalisation on VSS design and content constitute avenues for future research in this area.

Further research in these four areas is crucial to improve our understanding of the potential and limitations of VSS and the conditions under which they can contribute to sustainability. As VSS have become a mainstream governance instrument but are often criticised, research can not only help manage expectations about what VSS can and cannot achieve, but can also advise in optimising their design and inform policy making in the context of their increased integration in public policy.

We hope that this contribution further triggers interest in research on voluntary sustainability standards as one of the major areas of standards research.

Author Contributions: Introduction, A.M.; Institutional Design of VSS, A.M.; Effectiveness of VSS: Impact on Sustainability Dimensions, R.V.; Effectiveness of VSS: Adoption, C.D.; Institutionalisation of VSS, A.M.; Conclusion, A.M. All authors have read and agreed to the published version of the manuscript.

Funding: Research was funded by the GLOBE Project funded by the European Union's Horizon 2020 research and innovation programme (grant agreement no. 822654), as well as by the $\mathrm{VSS}^{\mathrm{F}} / \mathrm{WOOD} \mathrm{O}$ project (C2-project) funded by the University of Leuven (Belgium).

Conflicts of Interest: The authors declare no conflict of interest.

\section{References}

1. UNFSS. Voluntary Sustainability Standards. Today's Landscape of Issues and Initiatives to Achieve Public Policy Objectives; United Nations Forum on Sustainability Standards: Geneva, Switzerland, 2013.

2. UNFSS. Scaling up Voluntary Sustainability Standards through Sustainable Public Procurement and Trade Policy; United Nations Forum on Sustainability Standards: Geneva, Switzerland, 2020.

3. Scharpf, F.W. Governing in Europe: Effective and Democratic? Oxford University Press: Oxford, UK, 1999.

4. Auld, G.; Gulbrandsen, L.H. Transparency in Nonstate Certification: Consequences for Accountability and Legitimacy. Glob. Environ. Polit. 2010, 10, 97-119. [CrossRef]

5. Dingwerth, K. The New Transnationalism: Transnational Governance and Democratic Legitimacy; Springer: Cham, Switzerland, 2007.

6. Bennett, E.A. Who Governs Socially-Oriented Voluntary Sustainability Standards? Not the Producers of Certified Products. World Dev. 2017, 91, 53-69.

7. Gulbrandsen, L.H. Overlapping Public and Private Governance: Can Forest Certification Fill the Gaps in the Global Forest Regime? Glob. Environ. Polit. 2004, 4, 75-99. [CrossRef]

8. Gulbrandsen, L.H. Accountability Arrangements in Non-State Standards Organizations: Instrumental Design and Imitation. Organization 2008, 15, 563-583. [CrossRef]

9. Koppell, J.G.S. Global Governance Organizations: Legitimacy and Authority in Conflict. J. Public Adm. Res. Theory 2008, 18, 177-203. [CrossRef]

10. Marx, A. Legitimacy, Institutional Design, and Dispute Settlement: The Case of Eco-Certification Systems. Globalizations 2014, 11, 401-416. [CrossRef]

11. Bernstein, S.; Cashore, B. Can Non-State Global Governance Be Legitimate? An Analytical Framework. Regul. Gov. 2007, 1, 347-371. [CrossRef]

12. Beisheim, M.; Dingwerth, K. Procedural Legitimacy and Private Transnational Governance: Are the Good Ones Doing Better? SFBGovernance Working Paper Series No. 14; Research Center (SFB) 700: Berlin, Germany, 2008.

13. Cashore, B. Legitimacy and the Privatization of Environmental Governance: How Non-State Market-Driven (NSMD) Governance Systems Gain Rule-Making Authority. Governance 2002, 15, 503-529. [CrossRef]

14. Auld, G.; Gulbrandsen, L.H.; McDermott, C.L. Certification Schemes and the Impacts on Forests and Forestry. Annu. Rev. Environ. Resour. 2008, 33, 187-211. [CrossRef]

15. Holvoet, B.; Muys, B. Sustainable Forest Management Worldwide: A Comparative Assessment of Standards. Int. For. Rev. 2004, 6, 99-122. [CrossRef] 
16. Marx, A. The Public-Private Distinction in Global Governance: How Relevant Is It in the Case of Voluntary Sustainability Standards? Chin. J. Glob. Gov. 2017, 3, 1-26. [CrossRef]

17. Auld, G. Constructing Private Governance: The Rise and Evolution of Forest, Coffee, and Fisheries Certification; Yale University Press: New Haven, CT, USA, 2014.

18. Bennett, E.A. Voluntary Sustainability Standards: A Squandered Opportunity to Improve Workers' Wages. Sustain. Dev. 2018, 26, 65-82. [CrossRef]

19. Grabs, J. Selling Sustainability Short? The Private Governance of Labor and the Environment in the Coffee Sector; Organizations and the Natural Environment; Cambridge University Press: Cambridge, UK, 2020. [CrossRef]

20. Locke, R.M. The Promise and Limits of Private Power: Promoting Labor Standards in a Global Economy, Richard M. Locke; Cambridge Studies in Comparative Politics; Cambridge University Press: Cambridge, NY, USA, 2013.

21. Marx, A.; Wouters, J. Redesigning Enforcement in Private Labour Regulation: Will It Work? Int. Labour Rev. 2016, 155, 435-459. [CrossRef]

22. Sabel, C.F.; O'Rourke, D.; Fung, A. Ratcheting Labor Standards: Regulation for Continuous Improvement in the Global Workplace. KSG Working Paper No. 00-010; Columbia Law and Economic Working Paper No. 185; Columbia Law School, Pub. Law Research Paper No. 01-21. KSG Working Paper No. 00-010; Columbia Law and Economic Working Paper No. 185; Columbia Law School, Pub. Law Research Paper No. 01-21. 2000. Available online: https://scholarship.law.columbia.edu/faculty_scholarship/1243 (accessed on 14 April 2021).

23. Esbenshade, J.L. Monitoring Sweatshops: Workers, Consumers, and the Global Apparel Industry; Temple University Press: Philadelphia, PA, USA, 2004.

24. Barenberg, M. Toward a Democratic Model of Transnational Labour Monitoring? In Regulating Labour in the Wake of Globalisation: New Challenges, New Institutions; Bercusson, B., Estlund, C., Eds.; Hart Publishing: Oxford, UK, 2008; pp. 37-65.

25. Barrientos, S. Corporate Social Responsibility, Employment and Global Sourcing by Multinational Enterprises; ILO: Geneva, Switzerland, 2003.

26. Collins, B.; Evans, A.; Hung, M.; Katzenstein, S. The New Regulators? Assessing the Landscape of Multi-Stakeholder Initiatives; MSI Integrity and Kenan Institute for Ethics, Duke University: Durham, CA, USA, 2017.

27. Fiorini, M.; Hoekman, B.; Jansen, M.; Schleifer, P.; Solleder, O.; Taimasova, R.; Wozniak, J. Institutional Design of Voluntary Sustainability Standards Systems: Evidence from a New Database. Dev. Policy Rev. 2019, 37, O193-O212. [CrossRef]

28. Marx, A. Varieties of Legitimacy: A Configurational Institutional Design Analysis of Eco-Labels. Innov. Eur. J. Soc. Sci. Res. 2013, 26, 268-287. [CrossRef]

29. Van der Ven, H. Beyond Greenwash: Explaining Credibility in Transnational Eco-Labeling; Oxford University Press: Oxford, UK, 2019

30. Auld, G.; Renckens, S.; Cashore, B. Transnational Private Governance between the Logics of Empowerment and Control. Regul. Gov. 2015, 9, 108-124. [CrossRef]

31. Mongabay. Conservation Effectiveness. Available online: https://news.mongabay.com/conservation-effectiveness / (accessed on 7 August 2021).

32. Evidensia. Visual Summaries-Evidensia. Available online: https://www.evidensia.eco/work-with-evidence/visualsummaries/ (accessed on 20 September 2021).

33. ITC. The Impacts of Private Standards on Global Value Chains: Literature Review Series on the Impacts of Private Standards-Part I; ITC: Geneva, Switzerland, 2011.

34. ITC. The Impacts of Private Standards on Producers in Developing Countries: Literature Review Series on the Impacts of Private StandardsPart II; ITC: Geneva, Switzerland, 2011.

35. ITC. The Interplay of Public and Private Standards: Literature Review Series on the Impacts of Private Standards, Part III. SSRN Electron. J. 2012. [CrossRef]

36. ITC. When Do Private Standards Work? Literature Review Series on the Impacts of Private Standards, Part IV. SSRN Electron. J 2012. [CrossRef]

37. FAO. Impact of International Voluntary Standards on Smallholder Market Participation in Developing Countries: A Review of the Literature; FAO: Rome, Italy, 2014.

38. Meridian Institute. Conservation Impacts of Voluntary Sustainability Standards: How Has Our Understanding Changed since the 2012 Publication of "Towards Sustainability: The Roles and Limitations of Certification?"; Meridian Institute: Washington, DC, USA, 2018.

39. Oya, C.; Schaefer, F.; Skalidou, D. The Effectiveness of Agricultural Certification in Developing Countries: A Systematic Review. World Dev. 2018, 112, 282-312. [CrossRef]

40. Evidensia. Evidensia-Overview. Available online: https://www.evidensia.eco/about-evidensia/overview / (accessed on 14 April 2021).

41. Evidensia. Approach and Methodology. Available online: https://www.evidensia.eco/about-evidensia/approach-methodology/ (accessed on 14 April 2021).

42. Mongabay. Evidence Types and Trends in Tropical Forest Conservation Literature. Trends Ecol. Evol. 2019, 34, 669-679. [CrossRef]

43. Mongabay. Mongabay Conservation Evidence Data Visualizations: Mongabay Conservation Evidence. Available online: https:/ / www.conservationeffectiveness.org/faq/ (accessed on 7 August 2021).

44. Marx, A.; Wouters, J. Is Everybody on Board? Voluntary Sustainability Standards and Green Restructuring. Development 2015, $58,511-520$. 
45. van Kooten, G.C.; Nelson, H.W.; Vertinsky, I. Certification of Sustainable Forest Management Practices: A Global Perspective on Why Countries Certify. For. Policy Econ. 2005, 7, 857-867. [CrossRef]

46. Bartley, T. Transnational Private Regulation in Practice: The Limits of Forest and Labor Standards Certification in Indonesia. Bus. Polit. 2010, 12, 1-34. [CrossRef]

47. Tayleur, C.; Balmford, A.; Buchanan, G.M.; Butchart, S.H.; Corlet Walker, C.; Ducharme, H.; Green, R.E.; Milder, J.C.; Sanderson, F.J.; Thomas, D.H.; et al. Where Are Commodity Crops Certified, and What Does It Mean for Conservation and Poverty Alleviation? Biol. Conserv. 2018, 217, 36-46. [CrossRef]

48. Marx, A.; Cuypers, D. Forest Certification as a Global Environmental Governance Tool: What Is the Macro-Effectiveness of the Forest Stewardship Council? Regul. Gov. 2010, 4, 408-434. [CrossRef]

49. Bartley, T. Institutional Emergence in an Era of Globalization: The Rise of Transnational Private Regulation of Labor and Environmental Conditions. Am. J. Sociol. 2007, 113, 297-351. [CrossRef]

50. Fransen, L. Corporate Social Responsibility and Global Labor Standards. Firms and Activists in the Making of Private Regulation; Routledge, Taylor \& Francis Group: London, UK, 2015.

51. Fransen, L. Why Do Private Governance Organizations Not Converge? A Political-Institutional Analysis of Transnational Labor Standards Regulation. Governance 2011, 24, 359-387.

52. Depoorter, C.; Marx, A.; Otteburn, K. Multi-Stakeholder Governance; GLOBE Report; GLOBE EU Horizon 2020 Framework Programme: Barcelona, Spain, 2021.

53. Tayleur, C.; Balmford, A.; Buchanan, G.M.; Butchart, S.H.M.; Ducharme, H.; Green, R.E.; Milder, J.C.; Sanderson, F.J.; Thomas, D.H.L.; Vickery, J.; et al. Global Coverage of Agricultural Sustainability Standards, and Their Role in Conserving Biodiversity. Conserv. Lett. 2017, 10, 610-618. [CrossRef]

54. Willer, H.; Sampson, G.; Voora, V.; Dang, D.; Lernoud, J. The State of Sustainable Markets 2019-Statistics and Emerging Trends; Report; International Trade Centre (ITC), International Institute for Sustainable (IISD), Research Institute of Organic Agriculture (FiBL): Geneva, Switzerland, 2019.

55. Meier, C.; Sampson, G.; Larrea, C.; Schlatter, B.; Voora, V.; Dang, D.; Bermudez, S.; Wozniak, J.; Willer, H. The State of Sustainable Markets 2020: Statistics and Emerging Trends; ITC: Geneva, Switzerland, 2020.

56. Dietz, T.; Grabs, J.; Chong, A.E. Mainstreamed Voluntary Sustainability Standards and Their Effectiveness: Evidence from the Honduran Coffee Sector. Regul. Gov. 2019, 15, 333-355. [CrossRef]

57. Castka, P.; Corbett, C. Adoption and Diffusion of Environmental and Social Standards: The Effect of Stringency, Governance, and Media Coverage. Int. J. Oper. Prod. Manag. 2016, 36, 1504-1529. [CrossRef]

58. Galati, A.; Gianguzzi, G.; Tinervia, S.; Crescimanno, M.; La Mela Veca, D.S. Motivations, Adoption and Impact of Voluntary Environmental Certification in the Italian Forest Based Industry: The Case of the FSC Standard. For. Policy Econ. 2017, 83, 169-176. [CrossRef]

59. Zeitlin, J.; Overdevest, C. Experimentalist Interactions: Joining up the Transnational Timber Legality Regime. Regul. Gov. 2021, 15, 686-708. [CrossRef]

60. Gulbrandsen, L.H. Dynamic Governance Interactions: Evolutionary Effects of State Responses to Non-State Certification Programs Regul. Gov. 2014, 8, 74-92. [CrossRef]

61. Prado, A.M. Competition among Self-Regulatory Institutions: Sustainability Certifications in the Cut-Flower Industry. Bus. Soc. 2013, 52, 686-707. [CrossRef]

62. Garrett, R.; Pfaff, A. When and Why Supply-Chain Sustainability Initiatives "Work": Linking Initiatives' Effectiveness to Their Characteristics and Contexts; Meridian Institute: Washington, DC, USA, 2019.

63. Gereffi, G.; Garcia-Johnson, R.; Sasser, E. The NGO-Industrial Complex. Foreign Policy 2001, 125, 56. [CrossRef]

64. Marx, A. Limits to Non-State Market Regulation: A Qualitative Comparative Analysis of the International Sport Footwear Industry and the Fair Labor Association. Regul. Gov. 2008, 2, 253-273. [CrossRef]

65. Auld, G.; Bernstein, S.; Cashore, B. The New Corporate Social Responsibility. Annu. Rev. Environ. Resour. 2008, 33, 413-435. [CrossRef]

66. Marx, A.; Sharma, A.; Bécault, E. Voluntary Sustainability Standards: A Handbook; Klimos-Acropolis Report; Lirias: Leuven, Belgium, 2015.

67. Ponte, S. Business, Power and Sustainability in a World of Global Value Chains, 1st ed.; Zed Books: London, UK, 2019.

68. Rickenbach, M.; Overdevest, C. More than Markets: Assessing Forest Stewardship Council (FSC) Certification as a Policy Tool. J. For. 2006, 104, 143-147.

69. Faggi, A.M.; Zuleta, G.A.; Homberg, M. Motivations for Implementing Voluntary Environmental Actions in Argentine Forest Companies. Land Use Policy 2014, 41, 541-549. [CrossRef]

70. Takahashi, T. Why Firms Participate in Environmental Voluntary Initiatives: Case Studies in Japan and Canada. Ph.D. Thesis, University of British Columbia, Vancouver, BC, Canada, 2001.

71. Glasbergen, P. Smallholders Do Not Eat Certificates. Ecol. Econ. 2018, 147, 243-252. [CrossRef]

72. Stanton, G.H. Food Safety-Related Private Standards: The WTO Perspective. In Private Standards and Global Governance: Economic, Legal and Political Perspectives; Edward Elgar: Cheltenham, UK, 2012; pp. 235-254.

73. Ingenbleek, P.T.M.; Reinders, M.J. The Development of a Market for Sustainable Coffee in The Netherlands: Rethinking the Contribution of Fair Trade. J. Bus. Ethics 2013, 113, 461-474. [CrossRef] 
74. O'Rourke, D. Shopping for Good; MIT Press: Cambridge, MA, USA, 2012.

75. Brenton, S. The Political Motivations of Ethical Consumers. Int. J. Consum. Stud. 2013, 37, 490-497. [CrossRef]

76. Taufique, K.M.R.; Vocino, A.; Polonsky, M.J. The Influence of Eco-Label Knowledge and Trust on pro-Environmental Consumer Behaviour in an Emerging Market. J. Strateg. Mark. 2017, 25, 511-529. [CrossRef]

77. Thøgersen, J.; Haugaard, P.; Olesen, A. Consumer Responses to Ecolabels. Eur. J. Mark. 2010, 44, 1787-1810. [CrossRef]

78. Hainmueller, J.; Hiscox, M.J.; Sequeira, S. Consumer Demand for Fair Trade: Evidence from a Multistore Field Experiment. Rev. Econ. Stat. 2015, 97, 242-256. [CrossRef]

79. Marx, A.; Wouters, J. Competition and Cooperation in the Market of Voluntary Sustainability Standards. In The Law, Economics and Politics of International Standardisation; Delimatsis, P., Ed.; Cambridge University Press: Cambridge, UK, 2015; pp. 215-241. [CrossRef]

80. Schleifer, P.; Fiorini, M.; Fransen, L. Missing the Bigger Picture: A Population-Level Analysis of Transnational Private Governance Organizations Active in the Global South. Ecol. Econ. 2019, 164, 106362. [CrossRef]

81. Grabs, J.; Auld, G.; Cashore, B. Private Regulation, Public Policy, and the Perils of Adverse Ontological Selection. Regul. Gov. 2020, 15, 1183-1208. [CrossRef]

82. Depoorter, C.; Marx, A. Seeing the Trees for the Forest: Adoption Dynamics of the Forest Stewardship Council. Forthcoming.

83. Lambin, E.F.; Meyfroidt, P.; Rueda, X.; Blackman, A.; Börner, J.; Cerutti, P.O.; Dietsch, T.; Jungmann, L.; Lamarque, P.; Lister, J.; et al. Effectiveness and Synergies of Policy Instruments for Land Use Governance in Tropical Regions. Glob. Environ. Chang. 2014, 28, 129-140. [CrossRef]

84. European Union. Commission Initiative "Empowering the Consumer for the Green Transition": Have Your Say! European Circular Economy Stakeholder Platform. Available online: https:/ / circulareconomy.europa.eu/platform/en/news-and-events/ all-news/commission-initiative-empowering-consumer-green-transition-have-your-say (accessed on 12 February 2021).

85. Judge-Lord, D.; McDermott, C.L.; Cashore, B. Do Private Regulations Ratchet Up? How to Distinguish Types of Regulatory Stringency and Patterns of Change. Organ. Environ. 2020, 33, 96-125. [CrossRef]

86. Marques, J.C.; Eberlein, B. Grounding Transnational Business Governance: A Political-Strategic Perspective on Government Responses in the Global South. Regul. Gov. 2020, 15, 1209-1229. [CrossRef]

87. Wyatt, S.; Teitelbaum, S. Certifying a State Forestry Agency in Quebec: Complementarity and Conflict around Government Responsibilities, Indigenous Rights, and Certification of the State as Forest Manager. Regul. Gov. 2020, 14, 551-567. [CrossRef]

88. D'Hollander, D.; Marx, A. Strengthening Private Certification Systems through Public Regulation. Sustain. Account. Manag. Policy J. 2014, 5, 2-21. [CrossRef]

89. Marx, A. Public Procurement and Human Rights: Current Role and Potential of Voluntary Sustainability Standards. In Public Procurement and Human Rights; Edward Elgar Publishing: Cheltenham, UK, 2019.

90. Marx, A. Integrating Voluntary Sustainability Standards in Trade Policy: The Case of the European Union's GSP Scheme. Sustainability 2018, 10, 4364. [CrossRef]

91. Overdevest, C.; Zeitlin, J. Assembling an Experimentalist Regime: Transnational Governance Interactions in the Forest Sector. Regul. Gov. 2014, 8, 22-48. [CrossRef]

92. Ponte, S.; Daugbjerg, C. Biofuel Sustainability and the Formation of Transnational Hybrid Governance. Environ. Polit. 2015, 24, 96-114. [CrossRef]

93. Schleifer, P. Orchestrating Sustainability: The Case of European Union Biofuel Governance. Regul. Gov. 2013, 7, 533-546. [CrossRef]

94. Renckens, S. Private Governance and Public Authority: Regulating Sustainability in a Global Economy; Cambridge University Press: Cambridge, UK, 2020.

95. Bright, C.; Marx, A.; Pineau, N.; Wouters, J. Toward a Corporate Duty for Lead Companies to Respect Human Rights in Their Global Value Chains? Bus. Polit. 2020, 22, 667-697. [CrossRef] 